\title{
Synthesis and Application of Natural Polymeric Plasticizer Obtained Through Polyesterification of Rice Fatty Acid
}

\author{
Melissa Gurgel Adeodato Vieira ${ }^{a}$, Mariana Altenhofen da Silva ${ }^{a}$, André Costa Gomes Maçumoto ${ }^{a}$, \\ Lucielen Oliveira dos Santos ${ }^{b}$, Marisa Masumi Beppu ${ }^{a *}$ \\ ${ }^{a}$ School of Chemical Engineering, University of Campinas - UNICAMP, Av. Albert Einstein, 500, \\ Cidade Universitária "Zeferino Vaz”, CEP 13083-852, Campinas, SP, Brazil \\ ${ }^{b}$ School of Chemistry and Food, Federal University of Rio Grande - FURG, CP 474, \\ CEP 96201-900, Rio Grande, RS, Brazil
}

Received: April 16, 2013; Revised: January 7, 2014

\begin{abstract}
This study includes the synthesis of a new natural plasticizer obtained through esterification reaction of rice fatty acid and polyols, its physicochemical characterization and its preliminary application in polyvinyl chloride (PVC). Monopropylene glycol, octanol and diethylene glycol were used as polyols for esterification reaction. Catalyst Fascat ${ }^{\circledR}$ 4100, was also added. Viscosity, acidity and hydroxyl index, moisture content, molar mass, chemical composition (by FTIR) and color were determined to characterize the natural plasticizer synthesized. The results were compared with a commercial plasticizer (DOA: di-octyl adipate) derived from petrochemical source and synthesized in laboratory. According to the results, except from color, the natural plasticizer presented similar properties of commercially available plasticizers, such as DOA. Mechanical tests indicated that the addition of the natural plasticizer to PVC films resulted in a significant increase on its elongation at break $(371.2 \%)$ compared to pure PVC film, indicating a possible application for this plasticizer.
\end{abstract}

Keywords: esterification, fatty acid of rice, natural plasticizer

\section{Introduction}

Rice bran is a by-product of the rice milling process to produce white rice. Rice bran oil (RBO 20-25 wt\% in bran oil) is a mixture of esters of feluric acids with sterols and triterpene alcohols. The unsaponifiable content of RBO is approximately 4.0 to $5.0 \%$.

Plasticizers are an important class of non-volatile compounds of low molecular weight that are widely used as additives in the polymer industry ${ }^{1}$. They are necessary to maintain the film integrity, to avoid pores and cleavages ${ }^{2}$, increase its flexibility, workability, or distensibility ${ }^{3-6}$.

Plasticizers are substances that, once incorporated to the polymeric matrix, reduce the deformation tension, hardness, density, viscosity, glass transition temperature ( $\mathrm{Tg}$ ) and electrostatic charge of a polymer, increasing at the same time its flexibility, resistance to fracture and dielectric constant, among other properties ${ }^{7}$. Other properties are also affected, such as crystallinity degree, optical clarity, electrical conductivity, fire behavior, biodegradability, etc 8 .

The efficiency of a plasticizer is dependent on its chemical structure, molecular weight and concentration. Its compatibility with the polymer is crucial for an effective plasticization, and is a function of molecules polarity and molecular configuration, i.e., the relative attraction between

*e-mail: beppu@feq.unicamp.br the polymer and plasticizer, as well as solubility parameters and dielectric constant ${ }^{10}$.

Most plasticizers are usually prepared via esterification reaction between corresponding acids/anhydrides and alcohols in the presence of acid catalysts ${ }^{1}$.

The use of natural plasticizers, characterized by low toxicity and good compatibility with several plastics, resins, rubbers and elastomers, in substitution to conventional plasticizers has become more and more attractive and has also motivated extensive research in the industrial and academic areas ${ }^{2-4,11-16}$. The application of phthalates as plasticizers is being questioned due to their toxicity induced by its migration. Indeed, the search for natural-based plasticizers is related to the increased interest of material researchers and industries in the development of new biobased materials, made from renewable and biodegradable resources with the potential to reduce the use of conventional plastic goods.

In this context, the aim of this study is to develop a natural plasticizer through the esterification reaction of rice fatty acid followed by its physical and chemical characterization for potential application in polymers such as polyvinyl chloride (PVC). The concept of this natural plasticizer can be considered as an attempt to reuse agricultural by-products and to develop non-toxic polymer additives. 


\section{Material and Methods}

\subsection{Rice fatty acid}

The fatty acid of rice oil distillate was provided by Wells-Nuodex (Indústria Química Ltda, Brazil), with chromatographic average composition of $22 \%$ of palmitic acid, stearic acid $5 \%$, oleic acid $33 \%$, linoleic acid $36 \%$ and $4 \%$ linolenic acid. The physical characteristics of the rice fatty acid are presented in Table 1.

\subsection{Synthesis of natural plasticizer}

The natural plasticizer was prepared using a basis of $400 \mathrm{~g}$ of reaction mixture, containing octanol (5 wt $\%$ ) diethylethylene glycol (10 wt $\%)$ monopropylene glycol $(5 \mathrm{wt} \%)$, rice fatty acid $(80 \mathrm{wt} \%)$ and Fascat ${ }^{\circledR} 4100$ Catalyst (Butyl stannoic acid with $56.85 \%$ Sn) $(0.004 \mathrm{wt} \%)$. Fascat ${ }^{\circledR}$ 4100 Catalyst is an amorphous white solid commonly used in the synthesis of saturated polyester resins and also used to produce polymeric plasticizers.

For the synthesis reaction the classical process was performed. The system was composed by a round bottom flask with 5 necks, an electric flask heating mantle, a distillation column (Vigroux $300 \mathrm{~mm}$ ), a straight pipe condenser, a mechanical stirrer with glass stem and Teflon helix and collection beaker. Nitrogen was used to promote an inert environment and a stirring level of $150 \mathrm{rpm}$ was maintained throughout the process. Glass beads (3-5 $\mathrm{mm}$ ) were added to the flask in order to promote turbulence during reaction. The esterification reaction was followed through hydroxyl and acidity index determination.

\subsection{Synthesis of commercial plasticizer}

A commercial plasticizer (DOA - dioctyl adipate) was synthesized in laboratory instead of using a standard grade from the market in order to validate the reaction system, as well as to compare the physico-chemical characteristics of the obtained products. The commercial plasticizer, synthesized from a derivative of the petrochemical chain (adipic acid), was produced using the same experimental system and conditions described for the natural plasticizer, taking a reaction time of 15 hours. The formulation ( $400 \mathrm{~g}$ basis of reaction mixture) contained octanol, diethylethylene glycol, monopropylene glycol, adipic acid and Catalyst Fascat $^{\circledR} 4100$ (Butyl stannoic acid with $56.85 \%$ Sn).

Table 1. Physical characteristics of rice fatty acid.

\begin{tabular}{cc}
\hline Characteristic & Material \\
\hline Aspect $\left(25^{\circ} \mathrm{C}\right)$ & Pasty yellow \\
Gardner Color & 6 max. \\
Iodine index $\left(\mathrm{cg} \mathrm{I}^{2} / \mathrm{g}\right)$ & $95-108$ \\
Saponification index $(\mathrm{mg} \mathrm{KOH} / \mathrm{g})$ & $196-206$ \\
Acidity index $(\mathrm{mg} \mathrm{KOH} / \mathrm{g})$ & $195-205$ \\
Moisture $(\%)$ & 0.5 max. \\
Unsaponifiables $(\%)$ & 3.0 max. \\
Title $\left({ }^{\circ} \mathrm{C}\right)$ & $27-34$ \\
\hline
\end{tabular}

\subsection{Natural plasticizer characterization}

\subsubsection{Viscosity determination}

The viscosity was determined using a Brookfield Rotatory Viscometer (Model LVDV II) with spindle number $18\left(25^{\circ} \mathrm{C}\right)$ at a rotation speed of $75 \mathrm{rpm}$.

\subsubsection{Acidity index}

Aliquots of approximately $1 \mathrm{~g}$ of plasticizer were diluted in $25 \mathrm{~mL}$ of a toluol/methanol solution $(2: 1)$ and titrated with alcoholic $0.1 \mathrm{M} \mathrm{KOH}$ solution, using phenolphthalein as indicator.

The acidity index $\left(\mathrm{I}_{\mathrm{ac}}\right)$, expressed in $\mathrm{mg} \mathrm{KOH} / \mathrm{g}$ sample is obtained by Equation 1 .

$I_{a c}=\frac{\left(V_{a}-V_{b}\right) \cdot 56,1 \cdot M}{m}$

where $\mathrm{V}_{\mathrm{a}}$ is the volume of $\mathrm{KOH}$ solution used in the sample titration $(\mathrm{mL}), \mathrm{V}_{\mathrm{b}}$ is the volume of $\mathrm{KOH}$ solution used in blank titration (mL), $\mathrm{M}$ is the molarity of the $\mathrm{KOH}$ solution (M) and $m$ is the sample mass (g).

\subsubsection{Color}

Color was determined in a colorimeter (Color Quest XE - Hunterlab, USA). Parameters L0* (luminosity), a0* (red-green) and b0* (yellow-blue) were determined for the pattern and compared with the plasticizer sample $\left(\mathrm{L}^{*}, \mathrm{a}^{*}\right.$ and $\left.\mathrm{b}^{*}\right)$. Equation 2 was used to calculate the color difference.

$\Delta E=\sqrt{(\Delta L *)^{2}+(\Delta a *)^{2}+\left(\Delta b^{*}\right)^{2}}$

where: $\Delta \mathrm{L}^{*}=\mathrm{L}^{*}-\mathrm{L} 0^{*} ; \Delta \mathrm{a}^{*}=\mathrm{a}^{*}-\mathrm{a} 0^{*}$ and $\Delta \mathrm{b}^{*}=\mathrm{b}^{*}-\mathrm{b} 0 *$.

\subsubsection{Hydroxyl index}

The hydroxyl index was determined according to ASTM standard method D4274-05 ${ }^{17}$. Aliquots of plasticizers were transferred to Erlenmeyer flasks containing $20 \mathrm{~mL}$ of acetylating solution (acetic anhydride and pyridine solution). The flasks were maintained in a thermostatic bath at $98^{\circ} \mathrm{C}$ for two hours. When room temperature was reached, $20-30 \mathrm{~mL}$ of distilled water and $1 \mathrm{~mL}$ of phenolphthalein were added. Then samples were titrated with standardized $\mathrm{NaOH}$ solution $(0.5 \mathrm{M})$. The hydroxyl number $\left(\mathrm{N}_{\mathrm{OH}}\right)$, expressed in $\mathrm{mg} \mathrm{KOH}$ (equivalent to hydroxyl groups) per g of sample is given by Equation 3 .

$N_{O H}=\frac{\left(V_{b}-V_{a}\right) \cdot 56,1 \cdot M}{m}$

where $\mathrm{V}_{\mathrm{a}}$ is the volume of the $\mathrm{NaOH}$ solution used in the sample titration $(\mathrm{mL}), \mathrm{V}_{\mathrm{b}}$ is the volume of the $\mathrm{NaOH}$ solution used in blank titration ( $\mathrm{mL}), \mathrm{M}$ is the molarity of the $\mathrm{NaOH}$ solution (M) and $m$ is the sample mass $(\mathrm{g})$.

\subsubsection{Molar mass distribution}

The molar mass and the polydispersity index of the natural plasticizer was determined by gel permeation chromatography (GPC) using a GPC Advanced System composed by a GPCmax - VE 2001 - Viscotek Module (bomb, degasser and automatic sampler) and a Viscotek Module TDA302 (oven for columns and detectors, refractometer, viscometer and light scattering $90^{\circ}$ ). Data 
was acquired using a Viscotek OmniSEC and control system v. 4.1.0.224 software.

The separation of sample components was achieved by using two Viscogel columns $(7.8 \times 300 \mathrm{~mm})$ from Viscotek, with molar mass up to 10 million Daltons. The temperature of the columns was maintained at $30^{\circ} \mathrm{C}$. Tetrahydrofuran was used as mobile phase (eluent) at a flow-rate of $1.0 \mathrm{ml} /$ min. The volume injected was $100 \mu \mathrm{L}$. Detectors calibration was performed using PS170K and $400 \mathrm{~K}$ patterns. The standard curve was obtained using THF solutions of known plasticizer concentration (1 to $7 \% \mathrm{~m} / \mathrm{m}$ ).

\subsubsection{Infrared Spectroscopy by Fourier Transform (FTIR)}

The chemical composition of the natural plasticizer was investigations through FTIR analysis using a Spectrum One - FT-IR spectrometer (Perkin Elmer, England). The absorption spectra was obtained using $\mathrm{CaF}_{2}$ cell in the range of 4000 to $850 \mathrm{~cm}^{-1}$

\subsubsection{Moisture content}

The moisture content of natural plasticizer (\%) was determined by Karl Fisher method (Metrohm, 758 KFD Titrino model) in triplicate.

\subsection{Preparation of pure and plasticized PVC films}

PVC films were prepared by casting, according to procedure described in Lindström and Hakkarainen ${ }^{18}$. In a glass beaker, $0.4 \mathrm{~g}$ of PVC K70 resin (Braskem, Brazil) was mixed with the natural plasticizer $(30 \mathrm{wt} \%$ in relation to $\mathrm{PVC}$ resin) followed by the addition of $9 \mathrm{~mL}$ of tetrahydrofuran. The mixture was homogenized using a magnetic stirrer for $10 \mathrm{~min}$ at room temperature $\left(25^{\circ} \mathrm{C}\right)$ and then the solution was casted in a clean Petri dish (diameter $14 \mathrm{~cm}$ ). The films were dried in ambient pressure and room temperature until complete solvent evaporation.

\subsubsection{Mechanical properties}

Tensile strength $(T S)$ and percentage tensile elongation at break $(E)$ of the PVC films were determined at room temperature using a TA.XT2 (Stable Microsystems SMD, England) according to ASTM standard method D882 ${ }^{19}$.
Films were cut into strips $(10 \times 2.54 \mathrm{~cm})$ and mounted between the corrugated tensile grips of the instrument. The initial grip spacing and cross-head speed were set at 50 $\mathrm{mm}$ and $0.1 \mathrm{~cm} / \mathrm{s}$, respectively. The tensile strength was expressed as the maximum force at break divided by the initial cross-sectional area of the film strip and the elongation at break as a percentage of the original length.

Thickness of films was measured using a digital micrometer (Mitutoyo, MDC-25S, Japan). Measurements were taken at ten different positions of the film surface and the mean value was determined.

\section{Results and Discussion}

\subsection{Synthesis of natural plasticizer}

During reaction time, 3 samples were taken for acidity and hydroxyl index determination. Tests were performed in duplicate. It was necessary 17 hours of reaction (with temperature above $210^{\circ} \mathrm{C}$ ) until an adequate acidity index was achieved (below 1\%). The amount of condensed liquid at the end of the reaction was $14 \mathrm{~mL}(11 \mathrm{~mL}$ water and $3 \mathrm{~mL}$ glycols).

\subsection{Synthesis of commercial plasticizer}

As for the natural plasticizer, 3 samples were taken for acidity and hydroxyl index determination during the esterification reaction for dioctyl adipate commercial plasticizer synthesis (DOA). Tests were performed in duplicate. It was necessary 29 hours of reaction (with temperature above $210^{\circ} \mathrm{C}$ ) until reaching an acidity index around $2.91 \%$. The amount of condensed liquid at the end of the reaction was $44 \mathrm{~mL}$ ( $38 \mathrm{~mL}$ water and $6 \mathrm{~mL}$ glycols).

\subsection{Natural plasticizer characterization}

\subsubsection{Physical characteristics of natural plasticizer}

Physical characteristics of the natural plasticizer based on rice fatty acid compared to the commercial plasticizer (DOA) are shown in Table 2. The results are within the

Table 2. Physical characteristics of natural and commercial plasticizers.

\begin{tabular}{|c|c|c|}
\hline Characteristic & Natural plasticizer & Commercial plasticizer (DOA) \\
\hline Physical state $\left(20^{\circ} \mathrm{C}\right)$ & Liquid & Liquid \\
\hline Acidity index & $8.8 \mathrm{mg} \mathrm{KOH} / \mathrm{g}(0.88 \%)$ & $29.1 \mathrm{mg} \mathrm{KOH} / \mathrm{g}(2.91 \%)$ \\
\hline Hydroxyl index & $23.87 \mathrm{mg} \mathrm{KOH} / \mathrm{g}$ of sample & $8.73 \mathrm{mg} \mathrm{KOH} / \mathrm{g}$ of sample \\
\hline Color & $\begin{array}{c}\text { Dark amber } \\
\text { Pattern: } \mathrm{L}_{0}^{*}=92.03 ; \mathrm{a}_{0}^{*}=-0.88 \\
\mathrm{~b}_{0}^{*}=0.63 \\
\text { Sample: } \mathrm{L}^{*}=9.53 ; \mathrm{a}^{*}=0.03 \\
\mathrm{~b}^{*}=4.99 \\
\Delta \mathrm{E}=83.12\end{array}$ & Dark amber \\
\hline Viscosity $\left(20^{\circ} \mathrm{C}\right)$ & $\mu=31.5 \mathrm{cP}$ & $\mu=15 \mathrm{cP}^{*}$ \\
\hline Moisture (Karl Fischer) & $0.76 \pm 0.03 \%$ (b. u.) & $2.67 \pm 0.44 \%$ (b. u.) \\
\hline Molar mass & $\begin{array}{c}\mathrm{Mn}=385 \text { Daltons }(383.5 \mathrm{~g} / \mathrm{mol}) ; \\
\mathrm{Mw}=55.276 \text { Daltons; } \\
\mathrm{Mw} / \mathrm{Mn}=143.393\end{array}$ & $\mathrm{Mn}=370 \mathrm{~g} / \mathrm{mol} *$ \\
\hline Flash Point & - & $190^{\circ} \mathrm{C}$ \\
\hline
\end{tabular}

\footnotetext{
*Averages values obtained from manufacturer.
} 
typical values for both plasticizers, except from color, for which a light yellow color was expected. New tests, with addition of a natural antioxidant will be performed, in order to prevent darkening/oxidation of the final product.

It can observe that the hydroxyl and acidity index of natural plasticizer, measured after 17 hours of reaction, are close to the typical values of commercial plasticizers (hydroxyl index $\approx 20 \mathrm{mg} \mathrm{KOH} / \mathrm{g}$ and acidity index $<0.5 \%$ ).

Both plasticizers can be considered "monomeric", showing molar masses lower than $500 \mathrm{~g} / \mathrm{mol}$. Low molar mass plasticizers can be more easily incorporated to polymers, however, they can also show low permanence, i.e., they are easily removed from polymeric matrix. The permanence of a plasticizer in a polymeric matrix is deeply related with volatility, resistance to migration and extraction by water, solvents and fuels.

Considering homologous chemical substances, the higher the plasticizer molar mass is, the higher is the flash point and, consequently, the lower is the volatility. The flash point of the natural plasticizer was not determined, but it is expected to be closer to the value of the commercial plasticizer (DOA).

\subsubsection{Chemical composition analysis by FTIR}

Fourier Transformed Infrared Spectroscopy was performed to identify organic groups present in the synthesized natural plasticizer. The natural plasticizer is resultant of polyesterification reaction between rice fatty acid and polyols in presence of a catalyst, and has as products, esters and water. The release of water during the synthesis process, the decreasing values of hydroxyl and acidity index, as well as the characteristic esters peaks in FTIR spectrum confirm the occurrence of the esterification reaction.

The FTIR spectrum of the natural plasticizer with its respective identified peaks is shown in Figure 1. The absorption bands with correspondent groups and/or bindings are found in Table 3.

The peaks observed in Figure 1, refer to alkanes, alkenes and saturated aliphatic esters. Alkanes only have absorptions

Table 3. Absorption bands indentified in FTIR spectrum for the natural plasticizer.

\begin{tabular}{ccc}
\hline Binding or Function & $\begin{array}{c}\text { Absorption } \\
\left.\text { range } \mathbf{( c m}^{-1}\right)\end{array}$ & Attribution \\
\hline Alkene & 3007.73 & $\mathrm{v}=\mathrm{CH}$ or $\mathrm{vCH}_{2}$ \\
Alkane & 2924.88 & $\mathrm{v}_{\mathrm{as}} \mathrm{CH}_{2}$ \\
Alkane & 2853.82 & $\mathrm{v}_{\mathrm{s}} \mathrm{CH}_{2}$ \\
Saturated aliphatic ester & 1739.88 & $\mathrm{v}_{\mathrm{s}} \mathrm{C}=\mathrm{O}$ \\
Alkane & 1464.8 & $\mathrm{v}_{\mathrm{as}} \mathrm{CH}_{3}$ or $\delta_{\mathrm{s}} \mathrm{CH}_{2}$ \\
Alkane & 1378.23 & $\delta_{\mathrm{s}} \mathrm{CH}_{3}$ \\
Alkane & 1349.38 & $\mathrm{v}_{\mathrm{s}} \mathrm{CH}$ \\
Saturated aliphatic ester & 1243.58 & $\mathrm{vC}-\mathrm{CO}-\mathrm{O}$ \\
Saturated aliphatic ester & 1179.64 & $\mathrm{vC}-\mathrm{CO}-\mathrm{O}$ \\
Saturated aliphatic ester & 1137.61 & $\mathrm{vO}-\mathrm{C}-\mathrm{C}$ \\
\hline
\end{tabular}

$v$ : Symmetric vibration, $v$ asymmetric vibration, $\delta$ : symmetric angular deformation in plan, $\omega$ : symmetric angular deformation out plan ("wagging"), $\tau$ : symmetric angular deformation out plan ("twisting"). due to $\mathrm{C}-\mathrm{H}$ and $\mathrm{C}-\mathrm{C}$ stretching vibrations; and $\mathrm{C}-\mathrm{C}-\mathrm{C}$ and $\mathrm{H}-\mathrm{C}-\mathrm{H}$ angular deformation vibrations. The weak band in $3007.73 \mathrm{~cm}^{-1}$ is related to $\mathrm{C}-\mathrm{H}$ stretching binding of $\mathrm{sp}^{2}$ carbon, and therefore to unsaturation content. It is found that the more intense this band, the richer is the compound in double bindings. In the $3000-2850 \mathrm{~cm}^{-1}$ range, two bands can be observed due to symmetric and asymmetric stretching of $\mathrm{CH}_{3}$ and $\mathrm{CH}_{2}$ bindings. In $1465 \mathrm{~cm}^{-1}, v_{\text {as }} \mathrm{CH}_{3}$ usually overlaps with the $\delta_{\mathrm{s}} \mathrm{CH}_{2}$ band. In the absorption region of $1390-1370 \mathrm{~cm}^{-1}$, only one peak attributed to symmetric angular deformation of $-\mathrm{CH}_{3}$ group was observed ${ }^{20}$.

The saturated aliphatic esters show a band related to $\mathrm{C}=\mathrm{O}$ binding stretching in region of $1750-1725 \mathrm{~cm}^{-1}$. There were also strong bands observed in $1275-1185 \mathrm{~cm}^{-1}$ and in $1160-1050 \mathrm{~cm}^{-1}$. The first involves the stretching between oxygen and carbonyl carbon, attached to $\mathrm{C}-\mathrm{C}$ binding stretching. The second is related to the stretching between oxygen atom and other carbon ${ }^{20}$.

The FTIR analysis was able to confirm the presence of ester groups in the obtained natural plasticizer.

\subsection{Mechanical properties of PVC films}

The values of the mechanical properties of PVC films are given in Table 4. The tensile strength (TS) accounts for the film mechanical resistance due to the cohesion between the chains, while the elongation at break (E) measures its plasticity, which is the capacity of the film to extend before breaking.

By looking at Table 4 it is possible to observe a significant influence of the addition of the natural plasticizer to PVC films. An increase of $371.2 \%$ (4.71 times higher for plasticized PVC) was observed for its elongation at break,

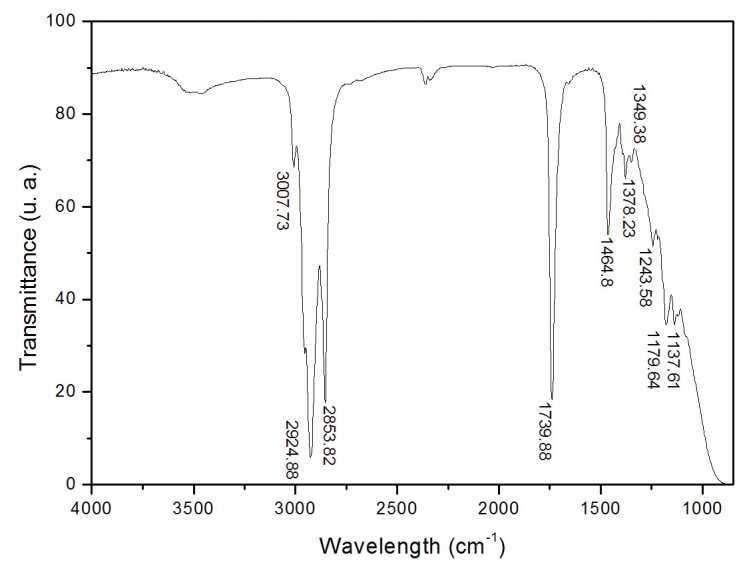

Figure 1. FTIR spectrum of natural plasticizer.

Table 4. Mechanical properties of pure PVC and plasticized PVC films.

\begin{tabular}{ccc}
\hline Film & TS (MPa) & E (\%) \\
\hline PVC & $45.39 \pm 4.64^{\mathrm{b}}$ & $22.18 \pm 2.53^{\mathrm{a}}$ \\
Plasticized PVC & $26.97 \pm 5.51^{\mathrm{a}}$ & $104.51 \pm 17.04^{\mathrm{b}}$ \\
\hline
\end{tabular}

Average \pm standard deviation of ten experimental determinations. Averages with the same letter in the same column indicates no significant difference $(\mathrm{p}<0.05)$ in Tukey test. 
and a consequent decrease in tensile strength of $40.58 \%$. These results indicate an expressive plasticization effect of the natural plasticizer synthesized. More experiments based on film impact strength, Young's modulus and flexural strength, for example, must be also conducted to better investigate this potential application.

\section{Conclusions}

The results showed that it is possible to obtain a natural plasticizer based on rice fatty acid, showing interesting properties compared to commercial plasticizer. The polyesterification reaction is essential in the synthesis process and several parameters influence in this stage.

The experimental set up used for this reaction showed satisfactory performance for both natural and commercial plasticizer synthesis. The natural plasticizer showed low molar mass, being therefore more easily incorporated into polymeric matrix. However, this characteristic can induce lower permanence and solvent extraction. The presence

\section{References}

1. Sejidov FT, Mansoori Y and Goodarzi N. Esterification reaction using solid heterogeneous acid catalysts under solventless condition. Journal of Molecular Catalysis A: Chemistry. 2005; 240(1-2):186-190.

2. Garcia MA, Martino MN and Zaritzki NE. Barrier properties of edible starch-based films and coatings. Journal of Food Science. 2000; 65(6):941-947. http://dx.doi. org/10.1111/j.1365-2621.2000.tb09397.x

3. Vieira MGA, Da Silva MA, Santos LO and Beppu MM. Natural-based plasticizers and biopolymer films: A review. European Polymer Journal. 2011; 47:254-263. http://dx.doi. org/10.1016/j.eurpolymj.2010.12.011

4. Da Silva MA, Vieira MGA, Maçumoto ACG and Beppu MM. Polyvinylchloride (PVC) and natural rubber films plasticized with a natural polymeric plasticizer obtained through polyesterification of rice fatty acid. Polymer Testing. 2011; 30:478-484. http://dx.doi.org/10.1016/j. polymertesting.2011.03.008

5. Faria-Machado AF, Da Silva MA, Vieira MGA and Beppu MM. Epoxidation of modified natural plasticizer obtained from rice fatty acids and application on polyvinylchloride films. Journal of Applied Polymer Science. 2013; 127(5):3543-3549. http://dx.doi.org/10.1002/app.37671

6. Donempudi S and Yaseen M. Controlled release PVC membranes: Influence of phthalate plasticizers on their tensile properties and performance. Polymer Engineering and Science. 1999; 39(3):399-405. http://dx.doi.org/10.1002/pen.11428

7. Rosen SL. Fundamental principles of polymeric materials. New York: John Wiley \& Sons, Inc.; 1993. p. 82-101.

8. Białecka-Florjańczyk E and Florjańczyk Z. Thermodynamics, Solubility and Environmental Issues. Oxford: Elsevier; 2007. p. 397-407. http://dx.doi.org/10.1016/B978-0444527073/50024-0

9. Savenkova L, Gercberga Z, Nikolaeva V, Dzene A, Bibers I and Kalnin M. Mechanical properties and biodegradation characteristics of PHB-based films. Process Biochemistry. of ester groups in the natural plasticizer was confirmed by FTIR analysis.

The addition of the natural plasticizer resulted in a significant increase in the elongation at break compared to PVC pure film, indicating an expressive plasticization effect of this substance. The incorporation of the natural plasticizer in PVC polymeric matrix showed promising preliminary results, glimpsing a potential application that will be further investigated.

A better understanding of the interactions between the bio/polymers and the natural plasticizer as well as and the knowledge of the fundamental physicochemical and biochemical properties are still needed in order to enable the production of materials using compatible plasticizers.

\section{Acknowledgements}

The authors would like to thank CNPq (Proc n. 150272/2009-0) and CAPES (Proc n. 1989/2008) for financial support.

2000; 35:537-579. http://dx.doi.org/10.1016/S00329592(99)00107-7

10. Van Oosterhout JT and Gilbert M. Interactions between PVC and binary or ternary blends of plasticizers. Part I. PVC/ plasticizer compatibility. Polymer. 2003; 44(26):8081-8094. http://dx.doi.org/10.1016/j.polymer.2003.09.065

11. Galdeano MC, Grossmann MVE, Mali S, Bello-Perez LA, Garcia MA and Zamudio-Flores PB. Effects of production process and plasticizers on stability of films and sheets of oat starch. Material Science and Engineering C. 2009; 29(2):492498. http://dx.doi.org/10.1016/j.msec.2008.08.031

12. Galdeano MC, Mali S, Grossmann MVE, Yamashita F and Garcia MA. Effects of plasticizers on the properties of oat starch films. Material Science and Engineering C. 2009; 29(2):532-538. http://dx.doi.org/10.1016/j.msec.2008.09.034

13. Rotta J, Ozorio RA, Kehrwald AM, Barra GMO, Amboni RDMC and Barreto PLM. Parameters of color, transparency, water solubility, wettability and surface free energy of chitosan/ hydroxypropylmethylcellulose (HPMC) films plasticized with sorbitol. Material Science and Engineering C. 2009; 29(2):619623. http://dx.doi.org/10.1016/j.msec.2008.10.032

14. Navarro-Tarazaga ML, Sothornvit R and Perez-Gago MB. Effect of plasticizer type and amount on hydroxypropyl methylcellulose_beeswax edible film properties and postharvest quality of coated plums (Cv. Angeleno). Journal of Agricultural and Food Chemistry. 2008; 56(20):9502-9509. http://dx.doi. org/10.1021/jf801708k

15. Audic J and Chaufer B. Influence of plasticizers and crosslinking on the properties of biodegradable films made from sodium caseinate. European Polymer Journal. 2005; 41(8):1934-1942. http://dx.doi.org/10.1016/j.eurpolymj.2005.02.023

16. Pommet M, Redl A, Morel M and Guilbert S. Study of wheat gluten plasticization with fatty acids. Polymer. 2003; 44(1):115122. http://dx.doi.org/10.1016/S0032-3861(02)00746-2

17. American Society for Testing and Materials - ASTM. Standard D4274-05. West Conshohocken: American Society for Testing and Materials; 1995. Annual Book of ASTM Standards. 
18. Lindstrom A and Hakkarainen M. Environmentally friendly plasticizers for poly(vinyl chloride)-Improved mechanical properties and compatibility by using branched poly(butylene adipate) as a polymeric plasticizer. Journal of Applied Polymer Science. 2006; 100(3):2180-2188. http://dx.doi.org/10.1002/ app.23633
19. American Society for Testing and Materials - ASTM. Standard D882. West Conshohocken: American Society for Testing and Materials; 1995. Annual Book of ASTM Standards.

20. Silverstein RM, Webster FX and Kiemle D. Spectrometric Identification of Organic Compounds. New York: John Wiley \& Sons, Inc.; 2005. p. 72-126. 